

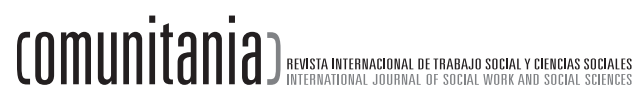

\section{Different routes to social security in Europe: social protection or social invesment (What determines the perception of social risks in relation to unemployment, care responsibilities and poverty? Rutas diferentes para la seguridad social en Europa: Protección Social o Inversión Social. iQué determina la percepción de los riesgos sociales relacionados con el desempleo, las responsabilidades asistenciales $y$ la pobreza?}

Anders Ejrnææ $y$ Thomas P. Boje*

* Department of Society and Globalisation. Roskilde University. P. 0. Box 260. DK-4000 Roskilde, Denmark. ejrnaes@ruc.dk \& boje@ruc.dk

\section{Abstrac:}

The article analyzes new social risks and how they are managed in different European social systems. We will focus on social risks that people in European countries are facing in the post-industrial society and how these risks are confronted by the welfare system.

One type of social risks comes from the inability to combine care for children and elderly relatives with paid work. Especially women are often forced to sacrifice employment in order to care for family members and have consequently a higher risk of poverty.

A second type of social risks relates to changes caused by technological innovations, industrial restructuring and global competition. Especially un-skilled male workers are hurt and have a higher risk of unemployment - followed by poverty and social exclusion.

The article examines how both institutional factors as family, labour market and welfare policy as well as individual factors as gender, education, age, and ethnicity affect patterns of perceived social risk. In analysing the perception of social risk we use comparative data from the fourth round of the European Social Survey carried out in 2008.

Keywords: New Social Risks; Unemployment, Work-family Conciliation, Poverty, Social Rights, Social Investments.

\section{Resumen:}

El artículo analiza los nuevos riesgos sociales y cómo se manejan en los diversos sistemas sociales europeos. Nos centraremos en los riesgos sociales que las personas están 
afrontando en las sociedades post-industriales europeas y en cómo estos riesgos se oponen al Sistema de Bienestar.

Un tipo de riesgo social viene de la imposibilidad de combinar el cuidado de los hijos y de las personas mayores con el desempeño laboral. Especialmente en el caso de las mujeres, que se ven forzadas a sacrificar su empleo para poder cuidar de los miembros de la familia y por tanto, aumentan su vulnerabilidad frente a la probreza.

Un segundo tipo de riesgo social está relacionado con los cambios derivados de la innovación tecnológicas, la reestructuración industrial y la competición mundial. Este riesgo afecta especialmente a los trabajadores varones sin especialización, lo que les lleva en primer lugar, a tener mayor probabilidad de sufrir un accidente o de perder el empleo, así como a sufrir la probreza y la exclusión social.

El artículo examina tanto los factores institucionales como familiares, el mercado de trabajo y las políticas de bienestar, así como factores individuales tales como el género, la educación, la edad, y los patrones étrnicos en cuanto al riesgo social percibido. Al analizar la percepción del riesgo social, usamos datos comparativos de la cuarta Encuesta Social Europea del año 2008.

Palabras clave: Nuevos riesgos sociales; Desempleo, conciliación trabajo-familia, pobreza, derechos sociales, inversiones sociales.

\section{Article info:}

Received: 06 / 10 / 2010 / Received in revised form: 27 / 12 / 2010

Accepted: 28 / 12/ 2010 / Published online: 03/01/2011

\section{Introducción:}

In this article we want to analyze the perceived social risks and how they are confronted in the different European social systems. We will focus on the social risks that people in the European countries are facing in the course of their lives as a result of the economic and social conditions prevailing in the present post-industrial society and how these risks are confronted by the welfare system.

The perception of social risk among citizens gives an indicator of the subjective feeling of insecurity and uncertainty during the life course. Perceived employment and social insecurity are detrimental to workers well-being, health and family life as well as family planning. Several studies have found that employment insecurity is correlated with poor health, low well being, family problem and low trust (Burchell 1994, Wichert 2002, Cheng and Chan 2008). Societal uncertainty has not only negative consequences for the individuals and the families it has also consequences for the society at whole. High level of societal uncertainty can lead to slump in consumer spending, low trust in the societal institutions, lack of mobility, migration, and a decline in fertility. Reducing the experience of insecurity and social risks could thus 
help to solve some of the major societal problems, which the European societies are confronted such as economic stagnation and demographic aging.

The acticle examines how both institutional factors as family, labour market and welfare policy and individual factors such as gender, education, age, and ethnicity affect the pattern of perceived social risk. We want to deal with three different types of social risks:

- Employment interruption caused by family responsibilities (spending less time on paid work because of care responsibilities)

- Employment interruption caused by unemployment

- Poverty (not having enough money to cover your household necessities)

The first two types of risk are connected to being in continuous employment or employability while the last risk is conditioned by both employment position and level of social protection. In managing different social risks the welfare state has traditionally promoted social security for the citizens through developing an income safety net. The welfare state in industrial societies is supposed to promoting full employment and organizing social provision for needs that market and family did not meet. During the 'golden age' of the welfare system it provided social security in periods of income interruption and organized social services for children, elderly and sick people to the extent that these services were not provided by family or civil society. This has changed throughout the post-industrial society where contingent forms of employment have replaced stable employment and industrial restructuring has demanded increased job qualification and advanced job flexibility. Furthermore women have taken up employment in large number and the traditional family-based social care has imposed strains on the family. All together these changes have created new social risks for individuals, families and introduced a new social agenda for the welfare system.

This article analyses level and distribution of social risks in relation labour market participation and social risks in relation to maintaining income and experiencing poverty in five EU countries representing different types of welfare and family regimes. The five countries included in the study are Denmark, Germany, Poland Spain and United Kingdom

The aim of the article is thus twofold.

- To analyse how the institutional setting of family, labour market, and welfare policies in the five countries influences the three types of perceived risk.

- To analyse the relationship between the perceived risk of employment interruption and the risk of poverty.

\section{New social risks in the post industrial society}

As a consequence of the transition from industrial society to post-industrialism the labour market has become more precarious, more feminized, more unequal and 
these developments have generated new social risks and new social needs (Bonoli 2005, Häusermann and Palier 2008). This development has again created a tension between the welfare arrangements designed for the industrial society and new demands in the labour market. Here we will focus on three different trends in the post-industrial society, which have created new types of risks and questioned the traditional welfare arrangements

\section{Flexibilisation of work and the risk of unemployment}

The transition from an industrial economy with stable employment in the manufacturing industry to a knowledge-based service economy has challenged the existing skill regime, which was designed to fit the demands of the industrial economy (Häusermann and Palier 2008). De-industrialisation and the vertical disintegration of large organizations and the entry of women into the labour market have lead to a spread of precarious work. Flexible specialization has characterised the radical changes in work organization that are arising in the wake of the decline of Fordist and bureaucratic organizational forms. New, more elastic, ways of adjusting work to the changing organizational forms in capitalistic production are reflected in the demands for flexibilisation of production. These changes have created new risks of labour market marginalization for vulnerable groups as youth, immigrants, and low skilled and a growing experience of employment insecurity. Sennett (Sennett 1998; Sennett 2006) describes how trends in society transform work and thereby influence societal cohesion. The rapid changes in the organization of production and global restructuring are based on information technologies, but also on the changing principles for organizing production (e.g. just-in-time, outsourcing, supplier base management, team work etc). The spread of flexibility strategies such as 'employment contracts' are perceived by some as undermining the traditional protection of working conditions.

\section{Feminization of the labour market}

Another major transformation in the post- industrial society has been the massive entry of women in the labour market and thereby changes in the traditional division of domestic work within families (Esping Andersen 2009). The implicit assumption that woman has responsibility for the unpaid care work in the private sphere while the man was responsible for wage work in public sphere has collapsed. The major driver behind this development has been the increasing educational level among women and the necessity of two wage earners to maintain a satisfactory family income (Taylor Gooby 2004). As a consequence of the entry of women on the labour market and lack of the welfare state's adaptation to women's new role, new social risks emerge. Several studies have shown that the impact of care responsibilities on women's employment affects the risk of poverty. Flexibility and family-friendly policies directed towards the new social risks might facilitate conciliation of work and care responsibilities and enable both parents to participate in paid work (Häuser- 
mann 2006). Reductions of time spend on paid work or employment interruption because of care responsibilities are under the present employment regime to be considered as a social risk.

\section{Rising income inequality and poverty}

The spread of post-industrial job leads to a polarized job structure with a focus on low skilled and high skilled job profiles. These trends are also reflected in a growing income inequality and a growing number of low-wage service jobs. Especially in the market-driven welfare states such as the UK and the US - working poor are a major problem. Labour market marginalization as a consequence of the changing demand for skills and the lack of work-family conciliation policies could also lead to risk of poverty. Particularly in welfare states with insufficient income maintenance programs labour market marginalisation leads to poverty and social exclusion.

\section{Different routes to social security: Protection or Investment}

In confronting the different social risks two visions of social citizenship regime have appeared in implementing welfare reforms: the social right regime based on Marshall (1949) and the social investment regime coined by Giddens (1998). The two regimes differ fundamentally when it comes to the notion of social security. In the social right regime social policy was primarily oriented towards consumption and income maintenance. The social right tradition argues that the welfare state through social rights can respond to the life risks encountered by the citizens such as sickness, unemployment, and old age. Following this approach the perception of income insecurity is not only related to employment insecurity but also to the level of generosity in the welfare state (Jenson and Saint-Martin 2003). According to Jenson and Saint-Martin it was the responsibility of welfare states to ensure economical growth with full employment and to ensure a more equal distribution of income than the market provides (Jenson \& Saint-Martin 2003: 91).

Due to societal changes - flexibilisation, feminization of labour market, and polarization of income - the conception of social security has changed. The old welfare state sought to protect people from the inequality that market creates, while the social investment state tries to facilitate integration into the market. In the social investment strategy security no longer means protection from the market or in Esping Andersen's terms a right to decommodification. Now social security means having the capacity to confront changes and this acquires new skills or update of old skills in order to adapt to the new demands in a knowledge-based economy (Jenson and Saint-Martin 2006: 435). Common for the social investment strategies is that they call for employment-related welfare reforms such as work-care conciliation, flexicurity and employability (Häusermann and Palier 2008). The social investment strategy can be divided into two strategies addressing different types of social risk - see table 1 


\section{Table 1 Social right and social investment regimes}

\begin{tabular}{|c|c|c|c|}
\hline Regime types & $\begin{array}{l}1 \text { Social investment } \\
\text { (child-care) }\end{array}$ & $\begin{array}{l}2 \text { Social investment } \\
\text { (human capital) }\end{array}$ & 3 Social right regime \\
\hline Notion of Risk & $\begin{array}{l}\text { Risk of employment } \\
\text { interruption because } \\
\text { of } \\
\text { care responsibilities }\end{array}$ & $\begin{array}{l}\text { Labour market } \\
\text { exclusion because } \\
\text { of lack of skills and } \\
\text { flexible labour } \\
\text { market }\end{array}$ & $\begin{array}{l}\text { Lack of income } \\
\text { because of life } \\
\text { course risks, } \\
\text { sickness, old age, } \\
\text { unemployment, care } \\
\text { responsibilities }\end{array}$ \\
\hline $\begin{array}{l}\text { Notion of } \\
\text { citizenship right }\end{array}$ & $\begin{array}{l}\text { Right to continuous } \\
\text { employment over a } \\
\text { life course for both } \\
\text { men and women }\end{array}$ & $\begin{array}{l}\text { Right to } \\
\text { employability } \\
\text { (employment } \\
\text { security) }\end{array}$ & $\begin{array}{l}\text { Right to income } \\
\text { security }\end{array}$ \\
\hline Policy measure & $\begin{array}{l}\text { Investing in child } \\
\text { care, Elderly care, } \\
\text { care for disabled } \\
\text { people }\end{array}$ & $\begin{array}{l}\text { Developing human } \\
\text { capital through } \\
\text { active labour market } \\
\text { policy, lifelong } \\
\text { learning, education } \\
\text { and vocational } \\
\text { training }\end{array}$ & $\begin{array}{l}\text { Income transfers, } \\
\text { unemployment } \\
\text { benefit, leave benefit, }\end{array}$ \\
\hline Social security & $\begin{array}{l}\text { Preventing poverty } \\
\text { by securing men and } \\
\text { women access to } \\
\text { paid work }\end{array}$ & $\begin{array}{l}\text { Preventing poverty } \\
\text { by developing } \\
\text { human capital for } \\
\text { vulnerable groups }\end{array}$ & $\begin{array}{l}\text { Reducing poverty by } \\
\text { income transfers }\end{array}$ \\
\hline Target group & $\begin{array}{l}\text { Women, parents } \\
\text { with small children, } \\
\text { lone mothers, } \\
\text { individuals with } \\
\text { special care need }\end{array}$ & $\begin{array}{l}\text { Youth, immigrants, } \\
\text { uneducated. }\end{array}$ & $\begin{array}{l}\text { Old, unemployed, } \\
\text { sick, individuals with } \\
\text { care responsibilities }\end{array}$ \\
\hline
\end{tabular}

The first social investment strategy focuses on investment in children and care. In this approach parents' inability to combine care obligations for children and elderly relatives with paid work can be considered as new social risks in the post-industrial society. The risk of poverty is caused by parents' difficulty of combining the family responsibilities with the demands of two full-time jobs. Dual income is a necessity in most families to maintain a satisfactory household income. Due to inequality in earnings and career between men and women it is typically the mother in a couple who is forced to sacrifice the career in order to bring up their children and carry on the domestic work. At the individual level the interruption in employment continuity decreases the life chances for women later in their life. Esping-Andersen is especially worried about child poverty and social exclusion of young and women. He fears that the society will polarise between work rich and work poor households. In this situation family-friendly policies have huge impact on women's life income in two ways. First it can prevent loss of income due to maternity interruption. Second it might through flexible working time arrangements prevent deprivation of human capital and loss of work experience caused among mothers by their work interrup- 
tions (Esping-Andersen 2009). Investment in childcare is in this context crucial and serves two purposes: 1) Affordable childcare helps parents to take up gainful employment and then move the family out of poverty. 2) Good quality childcare provides a good start for children. The social investment perspective thus considers childcare provision as a condition for mothers to remain in employment and thereby reduces the risk of social exclusion (Knijn and Smit 2009).

The second social investment strategy focuses on investment in human capital in order to avoid social exclusion of marginalised groups on the labour market. According to PeterTaylor Gooby the economic growth in the post-industrial society is lower and more uncertain and technological change means that stable employment in the manufacturing sector is no longer available (Taylor Gooby 2004). Labour market changes as a consequence of technological innovation; industrial restructuring and global competition have reduced the proportion of unskilled manual jobs and made the link between education and employment much closer. This development has especially hurt the unskilled male labour force which today has a higher risk of unemployment - followed by poverty and social exclusion - than women who in large number take up service jobs in the public sector.

The social investment strategy calls for deregulation of the labour market and a shift from passive benefits towards a system that give stronger incentives for entry into paid work together with massive investment in human capital (Taylor-Gooby 2008). The activation policies, which have been part of the welfare policy for vulnerable social groups in most EU-countries, are a crucial element in the social investment strategy. It considers investment in life long learning and education as a condition for employability and employment security. Investing in employability has thus become the standard answer to the growing job insecurity in the post-industrial society. A strong system of life-long learning and vocational training helps workers in risk of redundancy to transit both inside and outside the companies (Bekker \& Wilthagen 2008). Instead of job security workers get a transitional security or an employment security.

Common for both types of investment strategies is that the state should prioritize distribution and redistribution of opportunities and capabilities higher than resources (Jenson and Saint-Martin 2003). Both strategies also focus on labour market participation as the most effective way to prevent poverty and social exclusion (Jenson 2009). By investment in human capital and childcare the social investment strategy protects people from the risk of employment interruption caused by unemployment as a consequence of lacking skills or career interruption due to care responsibilities. Contrary to the social right regime social insecurity is caused by individuals' inability remaining in gainful employment. Investment in childcare and human capital is then a precondition for combating the risk of poverty because insecurity in employment is closely linked to income insecurity. Instead of reducing poverty by the means of income transfers the social investment strategy focuses on preventing poverty by investing in peoples' capability in realisation of their potential (Jenson 2009). 


\section{Different institutions, different outcomes}

We start our analysis describing how the social security and social investment strategies have been implemented in different EU countries. We have chosen five countries - Denmark, Germany, Poland, Spain, and the UK - that differ in relation to family, labour market, and welfare policies. Then follow a section analysing how differences in policy strategies affect the perceived social risk among EU-citizens in employment. First we give a brief outline of the variation in the institutional setting of labour market regulation and family - and welfare policies in order to formulate hypotheses about how the institutional setting affects the perception of social risks among employed individuals in the five countries. Two types of policies are in focus in this analysis: investment in care facilities to avoid interruptions in employment due to care obligations for both men and women and investment in human capital and flexibilisation of employment conditions to avoid the risk of unemployment and social exclusion.

\section{Investment in Care - reconciliation of work and care obligations}

The most comprehensive family policy when it comes to provision of care we find in Denmark. Denmark is characterised by a high level of childcare coverage among children aged 0-3 and parents with small children are able to return to their previous job after one year of maternal/parental leave because of affordable childcare facilities. The level of spending on both childcare and elderly care service is high - see table 2. Childcare provisions in UK have traditional been limited and privately provided. However, in the last 10 years the coverage rates for small children have expanded above the EU average but many childcare institutions are only available half-day or the attendance is costly.

Table 2 Investment in childcare and elderly care 2008

\begin{tabular}{|l|c|c|c|}
\hline & $\begin{array}{c}\text { Childcare } \\
\text { coverage for } \\
\text { children age 0-3) }\end{array}$ & $\begin{array}{c}\text { Childcare Spending } \\
\text { service as percent } \\
\text { GDP }^{2}\end{array}$ & Elderly care $^{\mathbf{3}}$ \\
\hline Denmark & 63,0 & 1,83 & 1.72 \\
\hline UK & 39,7 & 0,99 & 0.99 \\
\hline Spain & 33,9 & 0,69 & 0,34 \\
\hline Germany & 13,6 & 0,74 & 0.19 \\
\hline Poland & 8,6 & 0,29 & 0.23 \\
\hline
\end{tabular}

1 OECD Family database.

2 OECD Family database.

3 Eurostat. 
Spain is often characterised as a family care regime with a short period of mater$\mathrm{nal} /$ parental leave and insufficient childcare facilities and a low spending on elderly care (Boje and Ejrnæs 2010) but the number of childcare facilities have increased significantly as in the UK during the recent decade. Spain has a bi-modal employment pattern for women: either they return to the labour market quickly after a short maternity leave or they exit the labour market (Esping Andersen 2009). Germany and especially Poland have a low proportion of small children enrolled in formal childcare. The low childcare coverage for small children is combined with long periods of maternal and parental leave in both Poland and Germany. This family policy model encourages parents to stay home when the children are young. In Germany the long period of leave are combined with an increasing number of mothers in short parttime employment (see Boje and Ejrnæs 2010). This leads us to the first hypothesis.

\section{Hypothesis 1}

We assume that in countries with limited access to childcare as well as elderly care a greater proportion of workers are likely to spend less time on paid work because of caring for family or relatives. Countries with high investment in care are on the other hand expected to have the smallest proportion of employees that perceive a risk of employment interruption due to caring for family and relatives. We expect that employees in Poland have the highest risk of spending less time on paid work while Danish workers have the lowest perceived risk of spending less time on paid work due to care for family or relatives. Among the employees it is parents with small children and women who are most likely to perceive a risk of spending less time on paid work.

\section{Investment in human capital and flexibilisation of employment}

The countries differ significantly concerning regulation of labour market and investment in human capital. Denmark and UK are the least regulated and most flexible labour markets when it comes to job protection. As a consequence of the low level of job protection the proportion of temporary employees are low. Furthermore, Denmark followed by UK has the highest percentage of population participating in education and training. The two countries combine a high level of flexibility for all employees with a high level of employability through life long learning. Both countries have been able to combine flexible employment relations, high level of job mobility and low level of unemployment. The route to employment security is created by employability instead job protection - see table 3 . 
Table 3 Investment in Human Capital, employment regulation and unemployment 2008

\begin{tabular}{|l|c|c|c|c|}
\hline & $\begin{array}{c}\text { Life-long learning } \\
\text { Percentage of the } \\
\text { population aged 25- } \\
\mathbf{6 4} \text { participating in } \\
\text { education and } \\
\text { training over the four } \\
\text { weeks prior to the } \\
\text { survey 2008 }\end{array}$ & $\begin{array}{c}\text { Employment } \\
\text { protection in Scale } \\
\text { from 0 (least } \\
\text { restrictions) to 6 } \\
\text { (most restrictions) } \\
\mathbf{2 0 0 8}\end{array}$ & $\begin{array}{c}\text { Temporary } \\
\text { employees as a } \\
\text { percentage of the } \\
\text { total number of } \\
\text { employees 2008 }\end{array}$ & $\begin{array}{c}\text { Unemploy- } \\
\text { ment } \\
\mathbf{2 0 0 8}\end{array}$ \\
\hline Denmark & 30 & 1.91 & 8,1 & 3.3 \\
\hline United Kingdom & 20 & 1.09 & 5,2 & 5,6 \\
\hline Spain & 10 & 3.11 & 30,2 & 11,3 \\
\hline Germany & 8 & 2.63 & 14,7 & 7,3 \\
\hline Poland & 5 & 2.41 & 26,4 & 7,1 \\
\hline
\end{tabular}

Poland and Spain, on the other hand, are characterised by a dual labour market, with a segment of highly protected workers coexisting with a segment of unprotected temporary workers. One third of the Spanish and one-fourth of the Polish labour force are employment on temporary contracts. The stringent regulation of permanent employment contracts tends to foster a dual labour market structure. The percentages of population that participate in life-long learning are much smaller than in Denmark and UK. Germany holds a position in between the two extremes. The employment protection is high and few individuals participate in life-long training. The German labour market is characterised by a large proportion of companies with internal labour markets providing education and stable employment relations for the employees. This also means relatively few employees in temporary contracts and few individuals in open unemployment. That leads us to the second hypothesis.

\section{Hypothesis 2}

Employees in countries that provide employability instead of job protection are expected to be least likely to experience a risk of being unemployed. Employees in countries characterised by a dual labour market as we found in Spain and Poland are expected to be most likely to perceive a risk of being unemployed. When it comes to individual risks the most vulnerable groups in risk of being unemployment and experience poverty are immigrants, young people, and low educated individuals. Concerning the gender differences women typically take up part-time jobs and jobs in more precarious sectors, which might increase the risk of being unemployed. On the

\footnotetext{
4 Eurostat 2008.

5 OECD Employment Outlook 2010.

6 Eurostat 2008.

7 Eurostat 2008.
} 
other hand women are mainly employed in the service sectors, which are more secure than the male jobs in the manufacturing sector.

\section{Social security and inequality}

In traditional welfare research it is argued that social transfers and income maintenance policies reduce poverty. Income maintenance policy is aimed at redistribution of income, if employment is interrupted due to unemployment, caring for children or disability. Comparing the social security systems in the five countries we find considerable differences. Denmark is characterised by comprehensive social protection with a high level of income maintenance. In Denmark the replacement rate during unemployment is higher than the other countries. The same holds for compensation during maternal / parental leave. Germany comes next with a relative high level of income compensation during periods of unemployment benefit as well as during maternal / parental leave. This relatively high level of generosity in income compensation means that Denmark and Germany also have the lowest level of income inequality - see table 4.

Table 4 Generosity in social protections and income inequality

\begin{tabular}{|l|c|c|c|}
\hline & $\begin{array}{c}\text { Generosity of } \\
\text { unemployment benefits } \\
\text { Net- replacement rate in } \\
\text { percent. Five -years } \\
\text { average 20078. }\end{array}$ & $\begin{array}{c}\text { Generosity of leave system. full- } \\
\text { time equivalent of the leave } \\
\text { period if paid at 100\% of last } \\
\text { earnings, 2006/2007 in weeks }\end{array}$ & $\begin{array}{c}\text { Inequality of } \\
\text { income } \\
\text { distribution } \\
\text { S80/S20 income } \\
\text { 2008 quintile } \\
\text { share ratio }\end{array}$ \\
\hline Denmark & 56 & 50,0 & 3,6 \\
\hline United Kingdom & 28 & 9,3 & 5,6 \\
\hline Spain & 39 & 16 & 5,4 \\
\hline $\begin{array}{l}\text { Germany (including } \\
\text { ex-GDR from 1991) }\end{array}$ & 45 & 48,8 & 4,8 \\
\hline Poland & 16 & 34,1 & 5,1 \\
\hline
\end{tabular}

Poland, Spain, and UK, on the other hand, are characterised by a considerable lower level of income security. Poland and UK have the lowest level of income security for unemployed persons. When it comes to maternal and parental leave UK and Spain are in the bottom among the five countries with the least generous systems. Consequently, the UK has the highest level of income inequality among the five countries. One major problem in UK is the rise in the number of working poor (Esp-

\footnotetext{
OECD Employment Outlook 2010.

OECD Family database.

10 Eurostat.
} 
ing-Andersen 1999). Due to the high level of income inequality in UK we can expect that also workers in a secure labour market position could fear poverty. This leads us to two different hypotheses. One concerning the effects of the social investment strategy and another related to the social rights perspective.

\section{Hypothesis 3 Social investment perspective}

The country variation in risk of poverty can be explained by variation in the risk of employment interruption due to unemployment and care giving. The route to social security goes through creating conditions for workers to maintain in a continuous employment pattern. Avoiding employment interruption due to child rearing or unemployment is the most effective way to prevent poverty and feeling of insecurity.

\section{Hypothesis 4: Social rights perspective}

Countries with a high level of social protection through income transfers are expected to reduce the perceived risk of poverty independently of the risk of employment interruption. Welfare states with high level of social security protect people from poverty in periods of income interruption and / or during employment in low paid job. Securing a decent minimum income for person inside the labour market and outside the labour market is a condition for reducing a perceived risk of poverty.

In table 5 we have summarised our analysis of the differences in priorities made by the five countries in applying the social investment or the social rights strategy.

\section{Table 5 Social Investment versus social protection - differences between the five countries}

\begin{tabular}{|l|l|l|l|}
\hline & $\begin{array}{c}\text { Child care, elderly } \\
\text { care, care for } \\
\text { disabled people }\end{array}$ & $\begin{array}{c}\text { Active labour market } \\
\text { policy, lifelong le arning, } \\
\text { education and vocational } \\
\text { training, flexibility }\end{array}$ & $\begin{array}{c}\text { Income security } \\
\text { due to employment } \\
\text { interruption, } \\
\text { unemployment } \\
\text { benefit, leave } \\
\text { benefit, }\end{array}$ \\
\hline Denmark & High & High & High \\
\hline UK & Medium high & Medium high & Low \\
\hline Germany & Low & Medium low & Medium high \\
\hline Spain & Low & Medium low & Low \\
\hline Poland & Low & Low & Low \\
\hline
\end{tabular}


Denmark and Poland represent the two extremes. Denmark is characterised by both a high level of provision of public care facilities, emphasis on an active labour market policy and a high level of income security, while Poland score low on all three dimensions. In between we find the UK with a priority on the social investment strategy but a low level of social protection for vulnerable groups of employees. Spain and Germany are also placed in between both with low score on public care facilities, a modest level of investments in activation but different approaches to social protection. This is relative high in Germany both for unemployment and parental leave while it is low in Spain.

\section{The empirical analysis - methodology}

In testing the hypotheses we have used the European Social Survey (ESS) data from 2008. Three questions in the ESS dataset are used in order to measure the perceived social risk of unemployment, career break due to family responsibilities, and poverty.

- How likely it is that during the next 12 months you will be unemployed and looking for work for at least four consecutive weeks?

- How likely it is that during the next 12 months you will have to spend less time in paid work than you will like, because you have to take care of family members or relatives?

- How likely is it that there will be some periods when you don't have enough money to cover your household necessities

We restrict our sample to include only employees from Germany, Denmark, UK, Spain and Poland who have been in paid work within the last 7 days.

Answering the questions the respondents can choose one of four responses: (1) Not at all likely; (2) Not very likely; (3) Likely (4) Very likely. For the purpose of our analysis, we have for each of the questions merged the responses into a dummy variable with two categories 'likely and not likely.

We estimate three logistic regression models in order to predict the likelihood of perceiving social risk in relation to employment interruption and poverty. We include several independent variables into the statistical model that all have proved to be relevant from a theoretical and empirical perspective. According to the theory about new social risks low educated youngsters, immigrants, women, and parents with small children are most likely to be in the risk groups hidden by poverty and employment interruption. We therefore include variables that indicate the respondents' educational level, age group, gender, presence of small children, and whether the respondents are born in the country. We also include labour market related variables such as employment contract and number of working hours. 


\section{Social Risks related to Employment Interruption and Poverty - institutional or individual explanations}

In this section we shall analyse on the one hand the risk of being out of employment due to care responsibilities or unemployment and on the other hand the risk of poverty defined as not enough money to cover the daily expenditures of the household in case of employment interruption. First we describe the country variation in the three different forms of perceived risks and the relationship between the risk of employment interruption and the risk of poverty. Second we analyse the impact of individual and institutional variables on the country variations in the different types of social risks

\section{Country differences in perceived social risks}

There is marked country variation in the perceived risk of interruption in paid work due to care responsibilities or unemployment. The risks of employment interruption in relation to both care obligations and unemployment are lowest in Denmark and the UK - see table 6 . Both countries are characterised by a relative flexible labour market with a minimum employment regulation combined with a high level of investment in life-long learning and in childcare facilities which mean that the return to employment after periods on leave or unemployment takes place relatively uncomplicated and without extended periods of out of work.

Table 6 Country variation in perceived risk of employment interruption in relation to care and unemployment and the risk of poverty

\begin{tabular}{|l|c|c|c|}
\hline \multirow{2}{*}{} & \multicolumn{2}{|c|}{ The risk of employment interruption due to } & Perceived risk of \\
\cline { 2 - 4 } & Care & Unemployment & Poverty \\
\hline Germany & 12,1 & 16,3 & 13,4 \\
\hline Denmark & 7,4 & 10,1 & 5,2 \\
\hline Spain & 14,2 & 27,6 & 27,6 \\
\hline United Kingdom & 9,7 & 13,6 & 26,8 \\
\hline Poland & 24,9 & 26,6 & 33,3 \\
\hline Total & 13,0 & 18,6 & 20,7 \\
\hline
\end{tabular}

Source: European Social Survey 2008.

The highest proportion of employees who are in risk of employment interruption due to unemployment and care we found in Poland and Spain with Germany in a middle position. Especially in Poland the risk of employment interruption is high for both unemployment and care. Here parents have few possibilities combining work and care obligation because lack of childcare facilities and the risk of long-term 
unemployment is high due to lack of active labour market policy or retraining programmes. In Spain the risk of being unemployment in case of loosing your job is high. The main explanation for this is a divided labour market with a sector of protected and long-term jobs and a sector dominated of temporary and precarious jobs.

Looking at the perceived risk of poverty we found the lowest level in Denmark and Germany where the level of social protection is significant higher than in the other three countries. In the UK, Poland and Spain the risk of poverty is high - more that one-fourth of all employed in these countries indicate that they in periods do not have enough money to cover the daily household expenditures. For Poland and Spain is it probably not that surprising considering the high level of risks for employment interruption but it is interesting that the risk of poverty in the UK is high while the risk of employment interruption is low. This indicates that the traditional income transfer policies, which we found in Denmark and Germany but not in the UK seem to reduce the risk of poverty. The results show that the social investment strategy might reduce the risk of employment interruption as we saw in Denmark and the UK and partly in Germany but it does not prevent the risk of poverty. To reduce this type of social risk the social investment strategy has thus to be combined with adequate social protection through income transfers.

The relationship between risk of poverty and risk of employment interruption due to care responsibilities or unemployment is analysed more in detail in table 7. Here we have calculated the percentage of employees who are in poverty among employed persons that state they are likely / not likely to be unemployed and likely / not likely to reduce time in paid work due to care obligations. The table also shows the correlations between the employment related risks and the risk of poverty.

\section{Table 7 Risk of poverty among employees who are likely / not likel to experiences employment interruptions}

\begin{tabular}{|c|c|c|c|c|c|c|}
\hline & \multicolumn{6}{|c|}{ Risk of poverty } \\
\hline & $\begin{array}{c}\text { Not likely to } \\
\text { be } \\
\text { unemployed }\end{array}$ & $\begin{array}{l}\text { Likely to be } \\
\text { unemployed }\end{array}$ & $\begin{array}{l}\text { Correlation } \\
\text { coefficient } \\
\text { between } \\
\text { unemployment } \\
\text { risk \& poverty } \\
\text { risk }\end{array}$ & $\begin{array}{l}\text { Not likely } \\
\text { spend } \\
\text { less time } \\
\text { on paid } \\
\text { work } \\
\text { because } \\
\text { of care }\end{array}$ & $\begin{array}{l}\text { Likely to } \\
\text { spend less } \\
\text { time on paid } \\
\text { work } \\
\text { because of } \\
\text { care }\end{array}$ & $\begin{array}{c}\text { Correlation } \\
\text { coefficient } \\
\text { between Care risk } \\
\text { \& poverty risk }\end{array}$ \\
\hline Germany & $8,0 \%$ & $39,9 \%$ & 0,34 & $11,5 \%$ & $27,0 \%$ & 0,15 \\
\hline Denmark & $3,8 \%$ & $18,4 \%$ & 0,20 & $4,1 \%$ & $19,7 \%$ & 0,18 \\
\hline Spain & $13,4 \%$ & $64,5 \%$ & 0,51 & $21,8 \%$ & $58,9 \%$ & 0,29 \\
\hline United Kingdom & $22,9 \%$ & $52,4 \%$ & 0,23 & $24,6 \%$ & $48,8 \%$ & 0,16 \\
\hline Poland & $23,1 \%$ & $59,1 \%$ & 0,34 & $25,0 \%$ & $56,0 \%$ & 0,28 \\
\hline Total & $13,5 \%$ & $51,5 \%$ & & $16,9 \%$ & $44,9 \%$ & \\
\hline
\end{tabular}

Source: European Social Survey 2008. 
In Germany, Poland and especially Spain we find a strong correlation between risk of unemployment and risk of poverty. Employment insecurity is thus clearly associated with a high level of income insecurity. The strong correlation in Spain reflects the dual character of the labour market with a core workforce with permanent job and access to social security and an insecure group of workers in temporary job with no access to social security. Groups of employed persons in Spain who are in risk of labour market marginalisation are also in risk of poverty. In both Spain and Germany we have a divided and rigid labour market but the difference is that in Germany the level of social protection is relatively high while it is low in Spain and this explains the different outcome concerning the perceived risk of poverty.

In Spain and Poland we also find a stronger correlation between the risk of spending less time on paid work because of care responsibilities and the risk of poverty than in the other three countries. The explanations might here be that the income protection for parents who take parental leave are much lower in Spain and Poland than in Denmark and Germany. In Denmark and Germany individuals that say they are in risk spending less time on paid work do not fear poverty due to adequate income compensation. The low correlation between risk of employment interruption due to care obligations and risk of poverty in UK can be explained by the high number of working poor. Both those with risk og without risk of spending less time on paid work due to care obligations answer in relatively high numbers that they are in risk of poverty.

In Denmark and UK the correlation between the perceived risk of being unemployment and the risk of poverty is lower than in the other countries. The labour market in UK and Denmark are as mentioned earlier characterised by low job protection for all employees, high level of flexibility and high level of job mobility which makes it easier to shift between different job positions and between employment and unemployment. When it comes to regulation of salaries and social protection the difference between Denmark and the UK is pronounced. In UK a relative high proportion of employees in stable employment conditions answer that they are in risk of poverty. This can be explained by the high level of working poor which we find in the UK (Esping Andersen 1999 and 2009). In Denmark a relative small proportion of people, which consider themselves in risk of being unemployed answer that they are in risk of poverty. Here high levels of income compensation both in case of unemployment and parental leave protect the employed persons being in risk of employment interruption from the risk of poverty. We are talking about two different models in the relationship between risk of employment interruption and risk of poverty. The UK pursues a social investment strategy without social protection. This results for the UK are a relative high level of percieved poverty for both employed person with and without a risk of unemployment while Denmark combine a social investment startegy with adeqate social protection, which reduce the risk of poverty. 


\section{The relationship between institutional and individual explanations of social risks}

In this section we will analyse how individual and institutional factors affect the three different types of social risk. The logistic regression in table 8 shows how likely it is for employed persons to perceive social risk in relation to unemployment and to spend less time on paid work because of care.

In Spain and Poland employees are more likely to perceive a risk of being unemployed while Danish and British employees are less likely to perceive risk of unemployment compared with the reference country Germany. After controlling for individual factors this relationship between the countries remain and Poland and Spain is still significantly more likely to experience a risk of being unemployed than both Denmark and UK compared with Germany. These results confirm that highest level of perceived insecurity is in labour markets which are characterised by a dual structure dividing the labour force into a segment of workers in secure permanent positions and a segment of workers in temporary jobs. The results thus confirm hypothesis 1 that workers in countries like Denmark and UK that invest in workers' employability instead of job security through job protection are expected to be least likely to experience a risk of being unemployed.

Among the individual factors our analysis shows as expected that immigrants, low educated employees and employees in limited employment contracts are more likely to perceive a risk of unemployment. Surprisingly, we find no gender differences in the risk of unemployment. On the one hand women have less access to career jobs and are more likely to have part-time jobs and precarious jobs. On the other hand the increased participation of woman in the labour market has primarily been concentrated to service industries and the public sector while men are still dominating the manufacturing sectors, which are in decline in all five countries. It seems that these two tendencies have neutralized the gender effect.

When it comes to employment interruption because of care obligations Polish employees are significantly more likely to perceive risk of spending less time on paid work than employees in any of the other countries while Denmark hold the opposite position. The result confirms hypothesis 2 that employees in countries with high investment in care are less likely to perceive a risk of employment interruption due to care obligations for children or family relatives. In Poland the lack of care facilities, especially day care for small children, force parents in large number to interrupt employment.

Among the individual factors the results show that risk of employment interruption in paid work due to family responsibilities is significant higher for woman and employees with children under three. These findings confirm our expectation that woman are more in risk of employment break than men because of the unequal gender division of house - and care work within the family. Education has surprisingly no significant impact on the risk of interrupting paid work because of care obligations. 


\section{Table 8 Explaining risk of employment interruption}

\begin{tabular}{|c|c|c|c|c|}
\hline & \multicolumn{2}{|c|}{$\begin{array}{l}\text { Explaining perceived } \\
\text { unemployment risk }\end{array}$} & \multicolumn{2}{|c|}{$\begin{array}{l}\text { Explaining perceived risk spending } \\
\text { less time on paid work because of } \\
\text { care }\end{array}$} \\
\hline & Odds ratio & Odds ratio & Odds ratio & Odds ratio \\
\hline Denmark &, $57^{* * *}$ &, $58^{* * *}$ &, $62^{* *}$ &, $57^{* * *}$ \\
\hline Spain & $2,04 * * *$ & $1,36^{* *}$ & 1,25 & 1,02 \\
\hline United Kingdom & $0,66 * * *$ & $0,52 * * *$ & 0,82 & $0,70 *$ \\
\hline Poland & $1,93 * * *$ & $1,38 *$ & $2,46 * * *$ & $2,23 * * *$ \\
\hline Ref. Germany & 1.00 & 1.00 & 1.00 & 1.00 \\
\hline \multicolumn{5}{|l|}{ Age } \\
\hline Below 25 & & 0,92 & & 0,73 \\
\hline $26-35$ & & 1,22 & & 1,02 \\
\hline $36-45$ & & 1,27 & & 1,13 \\
\hline $46-55$ & & 1,00 & & 1,28 \\
\hline ref: above 56 & & 1.00 & & 1.00 \\
\hline \multicolumn{5}{|l|}{ Education } \\
\hline Primary & & $4,40 * * *$ & & 2,32 \\
\hline Secondary & & $2,67 * * *$ & & 1,66 \\
\hline ref: tertiary & & 1.00 & & 1.00 \\
\hline \multicolumn{5}{|l|}{ Nationality } \\
\hline Immigrant & & $1,55 * * *$ & & 1,29 \\
\hline ref. native born & & 1.00 & & 1.00 \\
\hline \multicolumn{5}{|l|}{ Gender } \\
\hline Woman & & 1,00 & & $1,65 * * *$ \\
\hline Re. Men & & 1.00 & & 1.00 \\
\hline \multicolumn{5}{|l|}{ Children } \\
\hline No small children & & 1,21 & & $0,40 * * *$ \\
\hline ref Smal children & & 1.00 & & 1.00 \\
\hline Woring hours & & ,99 & & ,99 \\
\hline \multicolumn{5}{|l|}{$\begin{array}{l}\text { Employment } \\
\text { contract }\end{array}$} \\
\hline Unlimited & &, $36 * * *$ & & 1,27 \\
\hline Limited & & $1,54 * * *$ & & $1,97 * *$ \\
\hline Ref: No contract & & 1.00 & & 1.00 \\
\hline $\mathrm{N}$ & & 4686 & & 4686 \\
\hline
\end{tabular}

Source: European Social Survey 2008.

According to the analysis four social groups are in risk of labour market marginalisation because of employment interruptions due to unemployment or care responsibilities: Low educated, immigrants, women and parents with small children. 
This confirms the social investment argument about the new social risk groups in the post-industrial society. According to this theory social policy should be focused on these vulnerable groups by investing in human capital and childcare to prevent social exclusion and poverty.

Now we shall continue analysing how the risk of poverty is perceived among employee in the five countries. The results show that employees in Poland followed by Spain and UK are significantly more likely to perceive a risk of poverty than the reference group Germany. Danish employees, on the other hand, are significantly less likely to perceive a risk of poverty - see table 9.

After controlling for individual factors in model 2 the odds ratio for Spain, UK, and Poland fall but are still significant higher than for Germany and Denmark. The risk of poverty is strongly associated with level of education. Investments in human capital seem to be the most efficient instrument reducing the perceived risk of poverty. Employees with a primary education or less have the highest risk of poverty of any social groups. Age has also significant impact on the perceived risk of poverty. The younger age groups are more likely to be in risk of poverty, the same concerns for women compared to men, immigrants compared to native employees and parents with small children compared to couples without children. This is again what can be characterised as the new social risk groups.

In model 3 we include also the two variables, which measure the risk of employment interruptions due to unemployment and the risk of spending less time on paid work because of care responsibilities. The central question is then to which extent country differences in the risk of poverty will be reduced or eliminated if we in the regression model control for the risks of employment interruptions. According to the social investment theory access to continuous paid work is the most effective way to prevent poverty and labour market marginalization. Our results also show that the perceived risks of employment interruptions are strongly associated with the risk of poverty. By including the risk of employment breaks due to unemployment and care obligations we confirm found that the odds of experiencing risk of poverty declined slightly among employees from Spain and Poland but increased considerably for the UK.

The UK has thus in model 3 the highest odds of perceived risk of poverty when we control for both the two risk variables and the individual variables. This indicates that a high level of income inequality and a low level social protection through income transfers in the UK can explain the high level of perceived risk of poverty even by employed persons in the UK. Consequently, it is not possible to achieve social security only by investing in the productive capacity of the employees and preventing them from labour market marginalisation. We therefore have to reject hypothesis 3 arguing that the primary explanation for country differences in perceived risk of poverty is variations in risk of employment interruption among the five countries. Differences in level of social protection and income inequality explain why UK has significantly higher odds of perceiving a risk of poverty than the other countries while Denmark has significantly lower odds. We can on the other hand confirm 
hypothesis 4 saying that a high level of income maintenance policy and income equality on the labour market reduces the risk of poverty independently of the risk of either being unemployed or spending less time on paid work.

Table 9 Explaining the perceived risk of poverty

\begin{tabular}{|c|c|c|c|c|c|c|}
\hline \multirow[b]{2}{*}{ Denmark } & \multicolumn{2}{|c|}{$\begin{array}{c}\text { Model } 1 \\
\text { Odds ratio }\end{array}$} & \multicolumn{2}{|c|}{$\begin{array}{c}\text { Model } 2 \\
\text { Odds ratio }\end{array}$} & \multicolumn{2}{|c|}{$\begin{array}{c}\text { Model } 3 \\
\text { Odds ratio }\end{array}$} \\
\hline & ,33 & $* * *$ & ,30 & $* * *$ & , & $* * *$ \\
\hline Spain & 2,31 & $* * *$ & 1,42 & $* *$ & 1,3 & \\
\hline United Kingdom & 2,34 & $* * *$ & 1,81 & $* * *$ & 2,3 & $* * *$ \\
\hline Poland & 2,84 & $* * *$ & 1,98 & $* * *$ & 1,7 & $* * *$ \\
\hline Ref: Germany & 1,00 & & 1,00 & & 1,00 & \\
\hline \multicolumn{7}{|l|}{ Age } \\
\hline below 25 & & & 2,45 & $* * *$ & 2,9 & $* * *$ \\
\hline $26-35$ & & & 2,30 & $* * *$ & 2,4 & $* * *$ \\
\hline $36-45$ & & & 2,50 & $* * *$ & 2,5 & $* * *$ \\
\hline $46-55$ & & & 1,73 & $* * *$ & 1,8 & $* * *$ \\
\hline \multicolumn{7}{|l|}{ ref: above 56} \\
\hline \multicolumn{7}{|l|}{ Education } \\
\hline Primary & & & 10,71 & *** & 8,7 & $* * *$ \\
\hline Secondary & & & 5,21 & $* * *$ & 4,7 & $* * *$ \\
\hline ref: tertiary & & & 1,00 & & 1,00 & \\
\hline \multicolumn{7}{|l|}{ Nationality } \\
\hline Immigrant & & & 1,35 & $*$ & 1,2 & \\
\hline Native born & & & 1,00 & & & \\
\hline \multicolumn{7}{|l|}{ Gender } \\
\hline Woman & & & 1,49 & $* * *$ & 1,5 & $* * *$ \\
\hline ref: men & & & 1,00 & & 1,00 & \\
\hline \multicolumn{7}{|l|}{ Children } \\
\hline No small children & & & \multicolumn{2}{|c|}{$0.78 *$} & 0,8 & \\
\hline Ref. small children & & & 1.00 & & 1.00 & \\
\hline Working hours & & & 1,00 & & 1,00 & \\
\hline \multicolumn{7}{|l|}{ Employment contract } \\
\hline Unlimited & & & 0,58 & $* * *$ & 0,7 & \\
\hline Limited & & & 1,23 & & 1,0 & \\
\hline Ref: No contract & & & 1,00 & & 1,00 & \\
\hline Likely to be unemployed & & & & & 4,8 & $* *$ \\
\hline $\begin{array}{l}\text { Likely to spend less time on paid } \\
\text { work because of care }\end{array}$ & & & & & 2,6 & $* * * *$ \\
\hline $\mathrm{R}$ & 0,09 & & 0,17 & & 0,29 & \\
\hline $\mathrm{N}$ & 4576 & & 4576 & & 4576 & \\
\hline
\end{tabular}

Source: European Social Survey 2008. 
However, it is worth mentioning that after inclusion of the variables measuring the risks of employment interruptions due to unemployment and care the explanatory power of the regression model increase from $17 \%$ to $29 \%$. This means that the experiences of insecurity on the labour market are an important predictor of the perceived risk of poverty. Our results assume that promoting social security and prevent poverty among the employees demands both investments in their capacity to confront challenges from the post-industrial society through human capital and employability and a certain level of social protection through income security.

\section{Conclusion}

The aim of the article has been to investigate how institutional and individual factors influence the perception of social risk and insecurity in relation to unemployment, work-family conciliation and poverty among employees in 5 European countries. The central question is how to promote social security in the post-industrial society. Social security and trust in the future among citizens are crucial for social cohesion and stability in European countries and a condition for solving central problems such as declining fertility, social exclusion, homophobia etc. We discuss two approaches to social security: social investment and social right / protection. In the empirical analyses we compare five European countries representing different welfare models and welfare strategies when it comes to both social protection, investment in human capital, and work-family reconciliation - see table 10 for summarising the results of our analyses.

\section{Table 10 The relationship between social investment and social protection in 5 European countries}

\begin{tabular}{|l|l|l|}
\hline & High social protection & Low social protection \\
\hline $\begin{array}{l}\text { High level of social } \\
\text { investment } \\
\text { (active labour market } \\
\text { measures childcare, life - } \\
\text { long learning, } \\
\text { employability) }\end{array}$ & $\begin{array}{l}\text { Low risk of unemployment and } \\
\text { spending less time on paid } \\
\text { work because of care and } \\
\text { poverty }\end{array}$ & $\begin{array}{l}\text { Low risk of unemployment } \\
\text { and spending less time on } \\
\text { paid work because of care. } \\
\text { High risk of poverty }\end{array}$ \\
\hline $\begin{array}{l}\text { Low level of social } \\
\text { investment }\end{array}$ & $\begin{array}{l}\text { Medium risk of unemployment } \\
\text { and spending less time on } \\
\text { paid work because of care. } \\
\text { Low risk of poverty }\end{array}$ & $\begin{array}{l}\text { High risk of } \\
\text { unemployment and } \\
\text { spending less time on } \\
\text { paid work because of care. } \\
\text { High risk of poverty }\end{array}$ \\
& Germany & \begin{tabular}{l} 
Poland and Spain \\
\hline
\end{tabular}
\end{tabular}


A major conclusion is that countries, which invest in childcare and human capital might be able reducing the risk of labour market marginalisation as a consequence of unemployment and work-family imbalance. In Poland and Spain which both are characterised by a high number of temporary workers, high unemployment, and low investment in both active labour market policy and family policy employees are more likely to perceive risks of unemployment and spending less time on paid work because of care responsibility. When it comes to the risk of poverty employees in the UK, Poland and Spain are more likely to perceive a higher risk of poverty than in Germany and Denmark. However, when controlling for the risks of employment interruption due to unemployment and care responsibility the perceived risk of poverty decreases for Poland and Spain while it increases in the UK. This shows that the risk of poverty not only are related to employment insecurity but also closely linked to level of social protection and income inequality in the labour market.

These results indicate that a combination of social investment in active labour market policy, life long learning and childcare combined with a high level of income security through unemployment benefit and family benefits as we see in Denmark might reduce all three kinds of social risks. A Danish combination of social investment measures and a high level of social security have clearly reduced the level of perceived social risk among Danish employees. However the central question is to what extent this model is feasible for other countries and is the Danish model sustainable in a period with large budget deficits around Europe. During the recent years Denmark has turned to a more liberal social investment strategy, which focuses on reduction of social benefits for the most vulnerable groups introducing stronger incentives for these groups to entry paid work instead of investments in their human capital. This has increased the social inequality and might probably also increase the perceived risk of social insecurity and poverty in the years to come.

A social investment strategy could reduce the income insecurity and the risk of poverty in Poland and Spain, where we find a widespread feeling of employment insecurity, and thereby contribute in solving the problems the South and Eastern European countries are facing such as low female rates of employment, high social inequality, and declining fertility. The UK have adopted a liberal social investment strategy that combine low job protection and low social protection with reforms that ensure investment in life-long learning and targeted childcare provision that enables marginal groups such as women, youth, and unskilled to participate in the labour market. However it seems that the main problem concerning the liberal social investment strategy is a growing income inequality, which leads to social insecurity and risk of poverty. The challenge for UK is to provide adequate instruments for poverty prevention for both the working population and groups who are not participating on the labour market.

\section{References}

Bekker, S. and T. Wilthagen. 2008. "Flexicurity ? a European approach to labour market policy". Intereconomics: Review of European economic policy 43 (2): 68-73. 
Boje, T. P and A. Ejrnæs. 2010. "Family Policy and Welfare Regimes" Article submitted for publication in European Journal of Social Policy.

Bonoli, G. 2005. "The politics of the new social policies: providing coverage against new social risks in mature welfare states". Policy \& Politics, Vol 33 (3): 431-449.

Burchell, B. 1994. "The effects of labour market position, job insecurity and unemployment on psychological health". In Gallie D. C. Marsh and C. Vogler (eds.): Social Change and the Experience of Unemployment, Oxford: Oxford University Press.

Cheng, GHL \& DKS Chan. 2008. "Who suffers more from job insecurity? A meta-analytic review". Applied Psychology-an International Review-Psychologie Appliquee-Revue Internationale. 57: 272-303.

Esping-Andersen, G. 1999. Social Foundations of Post industrial Economies. Oxford: Oxford University Press.

Esping-Andersen, G. 2009. The Incomplete Revolution: Adapting to Women's New Roles. Cambridge: Polity Press.

EUROSTAT Statistics 2008.

Giddens, A. 1998. The Third Way. The Renewal of Social Democracy. Cambridge: Polity Press.

Häusermann, S. 2006. 'Changing Coalitions in Social Policy Reforms: the Politics of New Social Needs and Demands'. Journal of European Social Policy 16, 1: 5-21.

Häusermann, S. and B. Palier. 2008. "State of the Art Report: The Politics of Employment-friendly Welfare Reforms". Socio-economic review 1-28.

Jenson, J. 2009. "Lost in Translation: The Social Investment Perspective and Gender Equality'. Social Politics 16, 4: 446-483.

Jenson J. \& D. Saint-Martin. 2003. "New Routes to Social Cohesion? Citizenship and the Social Investment State". Canadian Journal of Sociology 28: 2003.

Jenson J. \& D. Saint-Martin D. 2006. "Building blocks for a new social architecture: the LEGOTM paradigm of an active society". Policy \& Politics 34: 3.

Knijn, T. and A. Smit. 2009. "Investing, Facilitating, or Individualizing the Reconciliation of Work and Family Life: Three Paradigms and Ambivalent Policies". Social Politics 16, 4: 484-518.

Marshall, T.H. 1977. 1949. "Class, Citizenship and Social Development." In Essays by TH Marshall. Chicago: University of Chicago Prees.

OECD. 2010. Employment Outlook 2010. Paris OECD.

OECD Family database. Paris: OECD website June 2010.

Sennett, R. 1998 The Corrosion of Character - The Personal Consequences of Work in the New Capitalism. New York: W. W. Norton.

Sennett, R. 2006. The Culture of the New Capitalism. Princeton: Yale University Press.

Taylor-Gooby, P. 2004. New Risks, New Welfare: The Transformation of the European Welfare State. Oxford: Oxford University Press.

Taylor-Gooby, P. 2008 "The New Welfare Settlement in Europe". European Societies 10, 1: 3-24.

Wichert I. 2002 "Job insecurity and work intensification: the effects on health and wellbeing". Pp. 92-111. In B. Burchell, D Lapido D, and F. Wilkinson (eds). Job Insecurity and Work Intensification, London: Routledge. 


\section{comunitania)}

\section{Presentación/Presentation}

Antonio López Peláez

Presentación: Comunitania y Estado de Bienestar

Juan de Dios Izquierdo

\section{ARTICULOS/ARTICLES}

TThe current economic crisis in Ireland: Why social work needs to be part of the challenge to a discredited system / La actual crisis económica en Irlanda: ¿Por qué el trabajo social tiene que ser parte del desafío a un sistema desacreditado? Brid Featherstone

Welfare State and social policies in a time of economic crisis. The case of Denmark / Estados de Bienestar y las politicas

sociales en tiempos de crisis económica. El caso de Dinamarca

Bent Greve

Different routes to social security in Europe: social protection or social invesment (What determines the perception of social risks in relation to unemployment, care responsibilities and poverty? / Rutas diferentes para la seguridad social en Europa: Protección Social o Inversión Social. ¿Qué determina la percepción de los riesgos sociales relacionados con el desempleo, las responsabilidades asistenciales y la pobreza?

Anders Ejrnaes y Thomas P. Boje

La inacabada reforma psiquiátrica española: cuestiones sobre internamientos psiquiátricos no voluntarios y la ausencia de control judicial en los ingresos geriátricos / Involuntary psychiatric hospitalization under spanish law: applicability of judicial control of psychiatric hospitalization to geriatric admissions

$M^{a}$ Fernanda Moretón Sanz

La conciliación laboral y familiar en el modelo de flexiguridad en España desde una perspectiva de género / Flexicurity and work- family life balance in Spain from a gender perspective

Almudena Moreno Mínguez

La Convención ONU de 13 de diciembre de 2006: impulsando los derechos de las personas con discapacidad/The UN Convention of 13th December 2006: promoting the rights of disabled people Inmaculada Vivas Tesón

\section{RESEIIAS/REVIEWS}

Sagrario Segado Sánchez-Cabezudo. Nuevas tendencias en el Trabajo Social con Familias. Una propuesta para la práctica desde el empowerment New Trends in Social Work with Families. A Proposal for the practice from the empowerment. Madrid, Trotta 2011 (por Miguel del Fresno García)

Felipe Centellés, Rubén Darío Torres Kumbrián (eds.). La Fractura Social de Género en la Unión Europea. Los casos de Polonia y España / Social Gender Divide in the European Union. The cases of Poland and Spain. Toledo, Azacanes 2010 (por Patricia López Peláez)

Miguel del Fresno García. Retos para la intervención social con familias en el siglo XXI. Consumo, ocio, cultura, tecnología e hijos / Challenges for social intervention with families in the XXI century. Consumption, leisure, technology and children Madrid, Trotta 2011 (por Sagrario Segado Sánchez-Cabezudo)

Tomás Fernández García, Agnieszka Flisek, Grazyna Grudzińska, Urszula Lugowska, Rubén Darío Torres Kumbrián (eds.) América Latina: dos siglos de Independencia. Fracturas sociales, políticas y culturales / Latin America: two centuries of independence. Social, political and cultural divides. Varsovia, Instituto de Estudios Ibéricos e Iberoamericanos de la Universidad de Varsovia 2010 (por Katarsyna Moszczyńska)

Grażyna Grudizińska, Carolina Kumor, Katarzna Moszczyńska, Rubén Darío Torres Kumbrián (eds.). Transición en retrospectiva: los casos de Polonia y España / Retrospective transition: Poland and Spain cases. Varsovia, Instituto de Estudios Ibéricos e Iberoamericanos de la Universidad de Varsovia 2009 (por Laura Martínez Murgui)

Carlos Lasarte Álvarez, Fernanda Moretón Sanz (coords.). Residencias y alojamientos alternativos para personas mayores en situación de dependencia (Aspectos legales de la gestión, coordinación y acreditación en el SAAD de los servicios residenciales. Relevancia de los centros estatales de referencia y de la responsabilidad corporativa en la política social) / Homes and alternative housing for the elderly dependent (Legal aspects of management, coordination and accreditation of residential services SAAD. Relevance of main state institutions and corporate responsibility in social policies). Madrid Colex 2010 (por María Luz Rivera Fernández) 